\title{
Effects of metro transit on the ownership of mobility instruments in Xi'an, China
}

\author{
Xiaoyan Huang ${ }^{1}$, Xinyu (Jason) $\mathrm{Cao}^{2 *}$, Jiangbin Yin $^{1}$, Xiaoshu Cao ${ }^{1,3}$,
}

1 Northwest Land and Resources Research Center, Institute of Transport Geography and Spatial Planning, Shaanxi Normal University, China

2 Humphrey School of Public Affairs, University of Minnesota, Twin Cities, USA, cao@umn.edu

3 School of Geography and Planning, Sun Yat-sen University, China

*corresponding author

\begin{abstract}
Most studies regarding the effects of rail transit on auto ownership have yet to disentangle the influences of the built environment surrounding stations and residential self-selection from the impact of rail transit itself. There is also limited knowledge on the effects of rail investments in developing countries on ownership of mobility instruments, which has recently proliferated because of economic growth. Using the 2014 data from Xi'an, this study explores the joint influences of metro transit on the ownership of autos, bikes, ebikes, and motorcycles. The cross-sectional analysis shows that metro is negatively associated with auto ownership and ebike ownership whereas it has a positive association with bike ownership. The quasi-longitudinal analysis indicates that moving into metro neighborhoods is negatively associated with the changes of auto and ebike ownerships. These results suggest that metro development helps curb the growth of autos and fight against the negative consequences of ebikes, and has the potential to achieve sustainable travel.
\end{abstract}

Key words: auto ownership; bike ownership; transit-oriented development; residential self-selection; rail transit; sustainable travel 


\section{Introduction}

Increasing vehicular travel demand in urban areas has resulted in negative consequences such as traffic congestion and air pollution. It is widely acknowledged that the growth of auto ownership is a major cause of the deterioration of urban traffic conditions. In developing countries, auto ownership levels have grown substantially. In India, private auto ownership increased almost seven-fold between 1981 and 2002 (Pucher et al., 2005). In mainland China, the period between 1990 and 2013 has witnessed an increase of private auto ownership from 0.71 to 77 per 1000 people at the national level (National Bureau of Statistics of China, 2014). In the meantime, many cities worldwide, especially those in fast-growing developing countries, have made massive investments on rail systems and considered them an alternative to reduce individuals' reliance on automobile and mitigate traffic congestion and environmental impacts of transport (Bhattacharjee and Goetz, 2012; Garrett and Castelazo, 2004; Knowles, 1996).

Although previous studies have explored the influence of rail transit or transit-oriented development (TOD) on auto ownership, they share one or more limitations. They often compare TOD residents to people in the city/county/region where TOD is located (Gossen, 2005; Renne, 2005; Switzer, 2002). The control group is inappropriate (Cao and Cao, 2014; Cao and Schoner, 2014), because rail transit corridors tend to have a higher transit demand than the city/county/region as a whole even before its deployment (Guiliano, 2004). Moreover, most studies do not disentangle the influences of the built environment surrounding transit stations on auto ownership from the impact of rail transit itself, and hence it is uncertain what the observed impact on auto ownership is attributable to. Furthermore, few studies have considered the influence of residential self-selection on auto ownership. More importantly, we have a limited understanding of the capacity of rail transit or TOD in curbing auto ownership in developing countries where both auto ownership and rail investments are growing and multiple mobility instruments such as bikes and motorcycles co-exist. The choices of autos and other instruments may be related.

This study attempts to fill the gaps and explore the influences of metro transit on the ownership of four mobility instruments (autos, motorcycles, bikes, and ebikes) in a rapidly developing country, using a 2014 dataset in the City of Xi'an in China. We develop simultaneous mixed-process models to capture the joint influences of unobserved factors on instrument ownership. The paper is organized as follows. In the next section, we review previous studies and identify research gaps. Section 3 describes data and

variables. Section 4 presents the results. The final section summarizes the key findings and discusses their implications.

\section{Literature Review}

Many studies have explored the influence of the built environment on auto ownership. Various built environment elements have been taken into consideration, especially the "D variables" (Cervero and Kockelman, 1997; Ewing and Cervero, 2010; Ewing et al., 2009), such as density, diversity, design, demand management (e.g., parking supply and cost), destination accessibility, and distance to transit. The 
available evidence suggests that high density (Giuliano and Dargay, 2006; Goetzke and Weinberger, 2012; Hess and Ong, 2002) and mixed use (Kockelman, 1997; Soltani, 2005) are consistently associated with low auto-ownership rate. Some studies indicate that urban design such as street network characteristics and pedestrian environment can also impact auto ownership (Eash, 1997; Zegras, 2010). Several studies conclude that parking supply can significantly affect auto ownership decisions (Guo, 2013; Weinberger et al., 2009). Destination accessibility is usually measured as the distance to the central business district and job accessibility (distance to work). Many studies find that the former has a positive effect on car ownership (Van Acker and Witlox, 2010). The better the job accessibility, the lower the number of autos per capita (Gao et al., 2008). In terms of distance to transit, results are not always consistent. Many studies find that access to transit tends to dampen people's propensity to own vehicles (Holtzclaw et al., 2002; Kim and Kim, 2004; Van Acker and Witlox, 2010). However, other scholars argue that transit coverage and accessibility are not significant predictors for auto ownership (Potoglou and Kanaroglou, 2008; Soltani, 2005).

Although previous studies have considered the effect of transit on auto ownership by including the distance to the closest stop and/or the number of stops within walking distance in the models (Anastasopoulos et al., 2012; Li et al., 2010; Potoglou and Kanaroglou, 2008), transit is often not the focus in these studies. With the rising popularity of rail transit, some studies have examined the influence of rail transit or TOD on auto ownership. Using data from the 2000 San Francisco Bay Area Travel Study, Gossen (2005)finds that $70 \%$ of zero-vehicle households live within one mile of a Bay Area rail or ferry station and the mean number of vehicles per capita for residents within 1/4 mile of a transit station is 24\% lower than the overall mean for the Bay Area. A study of Santiago de Chile finds that households living within 500 meters of a Metro station are less likely to own two or more vehicles than households in other locations (Zegras, 2010). Using the data of residents in a recently developed suburban metro station area in Shanghai, Pan et al. (2013) examine how mass rapid transit (MRT) influences auto ownership and find that for households living in the station area, MRT has reduced the number of new autos. Switzer (2002) finds that $30 \%$ of respondents reduce their number of autos after moving into the Center Commons TOD. Using the census data, Renne (2005) examines the trends in auto ownership from 1970 to 2000 for households living in 103 TODs in 12 metropolitan regions and finds that TOD households are almost twice as likely to not own an auto as households in the metropolitan regions (18.5\% versus $10.7 \%$ ). Overall, TOD residents tend to have a lower auto ownership than those in other areas and they have a tendency to shed their vehicles after moving into TODs (Arrington and Cervero, 2008).

However, these studies have several limitations. Firstly, they often compare TOD residents to people in the city/county/region (Gossen, 2005; Renne, 2005; Switzer, 2002). Because rail transit is often planned in the key corridors that already have good bus service and high transit demand than the city/county/region as a whole (Guiliano, 2004), choosing residents in the city/county/region as control groups tends to overstate transport impacts of rail transit (Cao and Cao, 2014; Cao and Schoner, 2014). In a cross-sectional case-control design, it is ideal for control areas to have similar characteristics (in 
terms of location context, built environment elements and demographic profile) to treatment areas, except for the absence of rail transit.

Secondly, we are uncertain whether the observed impact on auto ownership is attributable to rail transit itself or the built environment surrounding rail stations. Chatman (2013) surveys households living within two miles of 10 rail stations in northern New Jersey and examines its impact on auto ownership. He finds that the low auto ownership in station areas is not due to rail transit itself, but built environment elements such as density, parking, and bus service.

Furthermore, a very limited number of studies have considered the influence of residential self-selection on auto ownership. Residential self-selection means that residential preferences and travel attitudes may be precedent factors for both choices of residential location and auto ownership. For example, transitliking people may simultaneously choose to live close to transit and not to own a personal automobile. If self-selection effect is not taken into account, the observed effect of the built environment on auto ownership may be "spurious" and hence misinform land use and transportation policies (Bhat and Guo, 2007; Cao, 2009). Using data from the 2000 US Census 5\% Public Use Micro Sample, Weinberger and Goetzke (2010) find that those relocating from large metropolitan areas tend to own fewer vehicles than others and conclude that these results may be due to the preferences for levels of auto ownership. Macfarlane et al. (2015) seek to relate a household's past experiences to its current vehicle ownership choices using a dataset that contains up to nine previous residential ZIP codes for households currently living in the 13-county Atlanta, Georgia, metropolitan area. They find that households with preferences to higher densities and non-vehicle transportation modes are less likely to own multiple vehicles. Bhat and Guo (2007) develop a joint mixed multinomial logit-ordered model for residential choice and auto ownership decisions of residents in the San Francisco Bay Area and conclude the important role of residential self-selection, particularly resulting from income. Cao et al. (2007) analyze built environment effects on auto ownership using both cross-sectional and quasi-penal data in Northern California. Their cross-sectional analysis indicates that residential self-selection explains all of the associations between built environment variables and auto ownership. On the other hand, their quasi-panel analysis shows that some aspects of the built environment do have a marginal influence on auto ownership. In terms of rail transit, Cao and Cao (2014) apply the statistical control approach and quasi-longitudinal design to examine the effects of the Hiawatha LRT in Minneapolis, neighborhood design and self-selection on auto ownership. They find that the LRT does not have an independent impact on auto ownership beyond neighborhood design and self-selection.

Studies in developed countries may have limited generalizability to developing countries. In developed countries, private vehicles dominate mode choice. In developing countries, as economy grows, transport mode has gradually experienced a transition from bikes, to motorcycles and ebikes, and to autos. All of the mobility instruments coexist in the transportation system. They (including transit) compete or complement with each other (Pinjari et al., 2011; Yamamoto, 2009). For example, bike can be used as a 
supplement to rail transit because it helps address the first/last mile connection to rail transit (DeMaio, 2009). The integration of bike and transit may make transit more competitive to private vehicles. Accordingly, when we investigate the influence of rail transit on auto ownership, we need to model various mobility instruments jointly. The literature on the relationships between the built environment and ebike/motorcycle ownership is rather limited (Zhang et al., 2013). Some studies have analyzed the influence of the built environment on bike ownership (Beck and Immers, 1994; Chatman, 2005; Renne, 2005; Xing et al., 2008). However, few studies have connected rail transit and bike ownership. Further, except for a few studies such as Pinjari et al. (2011), previous studies examine the ownership of only one type of mobility instruments. This study fills the gaps by applying joint mixed multinomial logit-ordered models to explore the impacts of metro transit on the ownership of four mobility instruments in China.

\section{Data and variables}

Our study area is Xi'an, located in Northwest China. As one of the most important cities in Chinese history, it has more than 3,000 years of history and was the capital for many important dynasties. The well-known Terra Cotta Warriors are located at the suburb of Xi' an. According to the 2010 Census, there were about 8.5 million permanent residents in Xi'an. During the past fifteen years, Xi' an has witnessed a proliferation in private auto ownership from about 45,000 in 2000 to 1.7 million in 2014 (Xi'an Bureau of Statistics, 2015). The growth in auto ownership and use has resulted in significant traffic jams and adverse environmental effects. These trends also appear in other cities in China. Accordingly, Chinese governments have regarded rail transit as an effective way to slow the increase in auto ownership. Xi'an is the 10th Chinese city that introduces a metro system. It has an ambitious long-term plan of 17 metro routes. Currently, Line 1 and Line 2 are in operation, and Line 3, Line 4, and Line 9 are under construction. The two operating lines total about $51 \mathrm{~km}$ and carried about 300 million passenger-trips in 2014.

The data came from a nine-page questionnaire administered in April - October, 2014. The survey was designed to explore the relationships between metro development and travel behavior. Because a random experiment is not feasible, this study employed a case-control observational design similar to Cao and Schoner (2014). It is ideal that case and control corridors have the same location context and built environment characteristics except for the presence of metro transit. In practice, there are no two same corridors in a region. In this study, we chose two parallel corridors. Specifically, the sampling frame contains neighborhoods located along two metro corridors: Line 2 (in operation) and Line 4 (under construction). For each of the two lines, we selected urban and exurban neighborhoods ${ }^{1}$ around existing stations (treatment/case) and future stations (control) (Figure 1). Specifically, Beidajie of Line 2 and

\footnotetext{
${ }^{1}$ We also selected suburban neighborhoods for each of the two lines. Because respondents in control neighborhoods are much more affluent than those in metro neighborhoods, we dropped the suburban neighborhoods for this analysis.
} 
Dachaishi of Line 4 are urban stations. Sports Park of Line 2, Fengcheng Nine Road and Fenxin Road of Line 4 are exurban stations, which are located about $12 \mathrm{~km}$ away from the urban center. We choose two exurban stations of Line 4 because there are fewer people living near Fengcheng Nine Road than Sports Park. We surveyed 59 residential complexes within 800 meters of these stations (Figure 2). The sample includes 782 respondents.

[Insert Figures 1 and 2 here]

As shown in Table 1, in both urban and exurban areas, there are no significant differences in the number of bus lines and road density (with 800 meters from the main entrance of residential complexes) between the residential complexes along Line 2 (called metro neighborhoods) and those along Line 4 (called control neighborhoods). However, metro neighborhoods have a significantly lower number of bus stops than control neighborhoods in both urban and exurban areas. Population density of metro neighborhoods is higher than that of control neighborhoods in both urban and exurban areas. Therefore, it is important to control for built environment elements in the models for mobility instruments.

\section{[Insert Table 1 here]}

The questionnaire was pretested by thirty residents living in those neighborhoods and then revised based on the feedback from pretesters. The survey was administered through structured face-to-face interviews. Specifically, we hired 25 undergraduate students from Shaanxi Normal University as interviewers. They received two-hour training before administering the survey. Respondents were recruited by knocking at the doors of residents and at open spaces and parks within the neighborhoods. Residential location was asked to make sure that respondents lived in our study areas. A small gift (less than 5 Yuan) was provided as an incentive for participation. Although we did not keep an accurate record on the number of people who refused to participate, the response rate is estimated at $60-70 \%$ based on the feedback from interviewers.

Table 2 illustrates demographic characteristics of urban and exurban samples for different corridors. Residents living in metro neighborhoods have a higher level of education and household income than those in control neighborhoods in both urban and exurban areas. Because transit is still a key mode of transport, Chinese often pay a substantial housing premium for access to metro transit in China (Gu and Zheng, 2010; Pan and Zhang, 2008). Respondents in metro neighborhoods have a larger household and are younger than those in control neighborhoods in urban areas, but the opposite holds true in exurban areas. There is no significant difference in the percentage of women between metro and control neighborhoods in urban areas, but there is a smaller share of female respondents in metro neighborhoods than control neighborhoods in exurban areas. Because population data at the neighborhood level are unavailable in China, we cannot evaluate the representativeness of our sample. However, since the focus of our study is on explaining the relationships of other variables to instrument ownership rather than on 
describing instrument ownership per se, these differences are not expected to materially affect the results (Babbie, 1998; Crano et al., 2015).

For the ownership of mobility instruments, there is no significant difference in auto ownership between metro neighborhoods and control neighborhoods for the entire sample, the subsample in urban areas, and the subsample in exurban areas. However, residents in metro neighborhoods tend to use transit more frequently than those in control neighborhoods (Huang et al., 2016). An ongoing research using the same data shows that there was no significant difference in driving distance between people in metro neighborhoods and those in control neighborhoods, but metro transit enables residents who moved into metro neighborhoods to experience a larger decrease in driving than those who moved into control neighborhoods. This is consistent with (Cao and Ermagun, forthcoming). Further, metro neighborhoods tend to own more bikes and motorcycles than control neighborhoods, but there is no significant difference in ebike ownership. The findings hold true for the subsample in urban areas. However, for the subsample in exurban areas, there is no significant difference in motor and ebike ownership, while metro neighborhoods tend to own fewer ebikes than control neighborhoods. Since these discussions are based on bivariate relationships, multivariate analyses are in order to control for potential confounding factors in the next section.

We differentiate movers and non-movers when we test the impact of metro on movers' changes in vehicle ownership. In the survey, respondents were asked to answer the question "When did you move to your current residence?" We define the "movers" as all current residents who had moved to the corridor after September 2006 when the construction of Line 2 started. In anticipation of Line 2, some residents may move into the neighborhoods before metro starts revenue service. We chose the construction date as the cutting point because after the date, people are sure that metro will come. The number of movers in urban and exurban areas is 595. Table 3 illustrates demographic characteristics of movers and non-movers for different corridors. In general, movers are younger, have a higher level of education and income than non-movers.

[Insert Tables 2 and 3 here]

The variables used in this study consist of five categories: ownership of mobility instruments, residential preferences and perception, travel attitudes, demographics, and objective neighborhood characteristics. Survey respondents were asked to report how many mobility instruments (including autos, motorcycles, electric bikes, and bikes) their households have currently (for both movers and non-movers) and how many mobility instruments their households have just before they move (for movers).

In terms of residential preferences, respondents were asked to indicate how important 27 characteristics (adapted fromCao et al. (2007)) were when they were looking for a place to live, on a four-point scale from "not at all important" (1) to "extremely important" (4). In terms of perceived neighborhood 
characteristics, respondents were asked to indicate how the 27 characteristics are like in their current (for both movers and non-movers) and previous (for movers only) residence and neighborhood, on a fourpoint scale from "not at all true" (1) to "entirely true" (4). We conducted a confirmatory factor analysis for 22 characteristics by polling residential preferences, current perception, and previous perception together. We obtained six latent constructs: safety, transit, accessibility, attractiveness, walkability, and socializing (Table 4). The difference of the six latent constructs between current and previous perceptions of neighborhoods is considered to be the change in the neighborhood characteristics after residential relocation. Thus, the six variables including changes in safety, transit, accessibility, attractiveness, walkability, and socializing were controlled in the model when analyzing the impacts of metro on change in the number of mobility instruments.

In the survey, respondents were asked to indicate the extent to which they agree or disagree with a number of statements about their attitudes toward daily travel on a five-point scale from "Strongly disagree" (1) to "Strongly agree" (5). Using a confirmatory factor analysis, we obtained five travel attitude factors: safety of auto, pro-transit, pro-drive, pro-bike, and pro-walk (Table 5).

[Insert Tables 4 and 5 here]

The survey also contained a list of demographic characteristics which explain respondents' mobility instrument choices. The demographics consist of gender, age, education, employment status, income, household structure, and so on.

Following the survey, we created a variety of objective neighborhood characteristic variables using ArcGIS 10.0. The variables include population density and road density of neighborhoods, transit routekilometers, the number of transit stops, intersections, and supermarkets with 800 meters from the entrance of residential complexes, network distance to the closest transit stop, distance to the closest metro station, and distance to the city center - Bell Tower.

\section{Modeling and Results}

\subsection{Current number of mobility instruments}

This study is to test the effects of metro transit on ownership of mobility instruments. Since the choice of mobility instruments is a collective decision, it is likely to be jointly influenced by unobserved factors, which are captured by the error terms of ownership equations. Ignoring the correlations among the error terms will produce statistically consistent but inefficient estimates. One of the approaches to address this issue is to develop mixed-process models. Because auto, bike and ebike ownerships include three categories $(0,1$, and 2 or more) and motorcycle ownership contains two categories ( 0 and 1 or more), we developed three ordered probit models and one binary probit model jointly using the "cmp" module in Stata 12.0 (Roodman 2011). The mixed-process models were developed using an incremental approach; 
that is, we allowed demographics to enter the model first, followed by neighborhood characteristics, travel attitudes and residential preference. Because we want to test the independent impacts of metro on the ownership of mobility instruments, we include a dummy variable indicating metro neighborhood in the models. Except for the metro dummy, the variables insignificant at the 0.1 level were manually removed to obtain parsimonious models.

Table 6 presents model results. As shown by the Rho values, the covariance of the error terms is significantly different from zero at the 0.10 level. Therefore, we should estimate the four equations jointly. The Rho values between auto and motorcycle, between auto and bike, and between auto and ebike are negative. This indicates that unobserved variables influence the ownership choices of auto and other mobility instruments in an opposite way. Specifically, if an unobserved variable negatively affects

auto ownership, it will positively influence motorcycle, bike, and ebike ownerships. This makes sense because autos compete with other mobility instruments. In contrast, as alternatives to auto, motorcycle, bike, and ebike ownerships are influenced by unobserved factors in the same way.

\section{[Insert Table 6 here]}

Out of the seven demographic variables, four are significant in the model for auto ownership; three are significant for motorcycle ownership; four are significant for bike ownership; and four are significant for ebike. Specifically, age and income are significant in all four models. Age and income are positively associated with auto ownership but negatively associated with the numbers of motorcycles, bikes and ebikes. These results are plausible since older people are on average more affluent than younger people and tend to have a higher propensity for auto ownership. Having a driver's license also has a positive association with auto ownership. The number of drivers in the household increases the propensity to own more autos and bikes. Household size is positively associated with motorcycle, bike and ebike ownership. These two variables make sense since more household members (or drivers) need more mobility instruments.

We test the perceived and objective neighborhood characteristics presented in the previous section. However, none of them are significant. Three travel attitude variables have associations with ownership of mobility instruments. Those who prefer driving tend to have a higher propensity for auto ownership than others. The pro-bike attitude has positive associations with the numbers of bikes and ebikes. Those who value the safety nature of autos tend to have a lower propensity to own bikes than others. These observed associations are consistent with our expectations. It is worth noting that we have also tested residential preference variables. However, they are insignificant and hence removed from the models.

The dummy variable of metro neighborhood is significant in the models for auto, bike and ebike ownership after controlling for demographics, neighborhood characteristics and attitudinal variables. As shown in Table 6, metro is negatively associated with the number of autos and ebikes but positively 
associated with bike ownership. The observed effect of metro on auto ownership is different from some studies in the U.S. Cao and Cao (2014) conclude that the Hiawatha light rail transit does not have an independent impact on auto ownership beyond neighborhood design and self-selection, and Chatman (2013) finds that it is neighborhood characteristics rather than light rail itself that contribute to the low level of auto ownership around station areas. The difference may be attributable to different types of rail transit: heavy rail tends to have a larger influence on travel choice than light rail. Further, auto ownership is almost saturated in the U.S. whereas the sales of autos have just proliferated in China during the past decade. It seems that rail transit plays a key role in shaping travel choice in developing countries: it slows the growth of auto ownership.

It is interesting that metro has opposite effects on the number of ebikes and bikes. Individuals who use metro transit are more likely to be physically active than others. The former may also use bikes for to access metro stations. It is not surprising that metro has a positive association with bike ownership. In contrast, although ebikes operate in bike lanes, they are "motorized" in nature. Accordingly, metro is negatively associated with the numbers of both ebikes and autos.

\subsection{Change in mobility instruments}

After residential relocation, changes in the number of autos, motorcycles, bikes and ebikes range from -1 to $3,-2$ to $2,-3$ to 4 , and -2 to 3 , respectively. Because a small number of respondents got rid of or acquired two or more vehicles, we recoded the change variables into three categories: shedding one or more instruments, no change, acquiring one or more instruments. We developed four ordered probit models jointly using the "cmp" module. To isolate the effects of changes in neighborhood characteristics on changes in instrument ownership, we estimated quasi-panel models for recent movers only. The explanatory variables contain changes in demographics (including household income and household size) and changes in perceived neighborhood characteristics (including safety, transit, accessibility, attractiveness, walkability, and socializing). However, none of the neighborhood characteristics are significant at the 0.1 level and hence were removed from the models.

Table 7 presents the model results. The Rho values between auto and ebike and between motorcycle and bike are significant. Therefore, we should estimate the four models jointly. In terms of demographic changes, change in household size is positive in all four models. This is plausible as an increase in household size tends to require additional mobility instruments. Change in household income is positively associated with change in auto ownership but negatively associated with change in bike ownership. The associations make sense.

\section{[Insert Table 7 here]}

For those who moved into metro neighborhoods, both auto ownership and ebike ownership have reduced. This suggests that metro is a competing mode to autos and ebikes. In other words, residents currently 
living in metro neighborhoods tend to have a larger decrease or a smaller increase in auto/ebike ownership than those in control neighborhoods.

It's worth noting that the models in Table 7 may underestimate the impacts of metro development on instrument ownership. Since metro construction may influence residential location choice, the "movers" in this study were defined as all current residents who had moved to the metro corridor after the construction of Line 2 started. Because the data were collected in April - October, 2014 and the construction of Line 4 started in January 2013, we cannot rule out the possibility that movers relocating into the neighborhoods along Line 4 after January 2013 were for metro transit. We tried to remove the movers who had relocated into the current neighborhood after January 2013 from the full sample. The total sample size reduces to 482. The new models (not shown) demonstrate that metro has a significant and negative effect on auto ownership and the coefficient grows from 0.339 (Table 6) to 0.462. But in the quasi-longitudinal models, the sample size is too small (295) and many variables are not significant.

\section{Conclusions}

Using the data from Xi'an, this study develops mixed-process models to examine how metro transit influences households' ownership of four mobility instruments (namely, autos, motorcycles, bikes, and ebikes), after controlling for objective neighborhood characteristics, demographics, and attitudes toward land use and travel. The results are consistent with our hypothesis that the ownership of different instruments is jointly influenced by unobserved factors. Thus, we should use a joint model for mobility instrument ownerships.

The cross-sectional analysis demonstrates that metro is negatively associated with auto ownership and ebike ownership whereas it has a positive association with bike ownership. The quasi-longitudinal analysis also shows that moving into metro neighborhoods is negatively associated with the changes of auto and ebike ownerships. As the changes in instrument ownership were measured after residential relocation, it suggests that metro enables residents to meet their daily needs even after shredding one or more autos/ebikes. On the other hand, it may mean that metro slows the growth in autos and ebikes when auto/ebike ownership increases in both metro and non-metro neighborhoods. Overall, metro development helps curb the growth of autos and ebikes.

Current sustainability policies often focus on rail investments and developing housing near rail stations, especially in developing countries. One of the goals of such policies is to reduce greenhouse gas emissions by replacing personal vehicle travel with transit or active travel. Our results suggest that metro development has the potential to reduce auto and ebike ownerships, and implicitly change the share of personal vehicle travel. Thus, rail investments can alleviate environmental impacts of transport and slow the growth of traffic congestion. Although ebikes do not produce tailpipe emissions, they consume electricity generated elsewhere with emissions. From the perspective of environmental 
protection, reducing ebike ownership also benefits the environment. The growth of ebikes has also been criticized for their contribution to congestion and accidents (Cherry et al., 2009). Therefore, metro development helps fight against the negative consequences of ebikes.

This study shows that the evidence in developed countries cannot be simply generalized to developing countries. In Xi' an, residents living close to metro stations are more affluent than those living away from the stations. This is reasonable because there is a substantial housing premium for access to metro transit in China (Gu and Zheng, 2010; Pan and Zhang, 2008). In contrast, the average income of residents living along rail transit in the U.S. tends to be lower than the regional average income (Barton and Gibbons, 2015; Bowes and Ihlanfeldt, 2001; Brueckner and Rosenthal, 2009). More importantly, metro transit itself dampens auto ownership in Xi'an whereas LRT does not have a separate effect on auto ownership in several regions in the U.S. (Cao and Cao, 2014; Chatman, 2013). These differences may result from the differences in transportation systems. In developed countries, auto is the dominant transport mode and installing a rail line does not substantially improve accessibility (Guiliano, 2004). But transit and nonmotorized transportation play a key role in the transportation systems in developing countries. A rail transit can greatly enhance accessibility, guide land development, and affect individuals' mobility decision.

\section{Acknowledgements}

The paper was developed from a project sponsored by the Natural Science Foundation of China (\#41401127 and \#41401180), and partially supported by the National Science Foundation of USA (PIRE \#1243535)

\section{References}

Anastasopoulos, P., Karlaftis, M., Haddock, J., and Mannering, F. (2012). Household automobile and motorcycle ownership analyzed with random parameters bivariate ordered probit model. Transportation Research Record: Journal of the Transportation Research Board 2279, 12-20.

Arrington, G., and Cervero, R. (2008). Effects of TOD on Housing, Parking and Travel. Transit Cooperative Research Program, Transportation Research Board, Washington, D.C.

Babbie, E. (1998). The Practice of Social Research 8th Edition. Wadsworth Publishing Company, CA.

Barton, M. S., and Gibbons, J. (2015). A stop too far: How does public transportation concentration influence neighbourhood median household income? Urban Studies, Published online before print, doi: 10.1 177/0042098015593462.

Beck, M. J., and Immers, L. (1994). Bicycle ownership and use in Amsterdam. In "Transportation Research Record 1441, TRB", pp. 147-150. National Research Council, Washington, D.C.

Bhat, C., and Guo, J. (2007). A comprehensive analysis of built environment characteristics on household residential choice and auto ownership levels. Transportation Research Part B: Methodological 41 (5), 506-526. 
Bhattacharjee, S., and Goetz, A. R. (2012). Impact of light rail on traffic congestion in Denver. Journal of Transport Geography 22, 262-270.

Bowes, D. R., and Ihlanfeldt, K. R. (2001). Identifying the impacts of rail transit stations on residential property values. Journal of Urban Economics 50 (1), 1-25.

Brueckner, J. K., and Rosenthal, S. S. (2009). Gentrification and neighborhood housing cycles: will America's future downtowns be rich? The Review of Economics and Statistics 91 (4), 725-743.

Cao, J., and Cao, X. (2014). The Impacts of LRT, Neighbourhood Characteristics, and Self-selection on Auto Ownership: Evidence from Minneapolis-St. Paul. Urban Studies 51 (10), 2068-2087.

Cao, X. (2009). Disentangling the influence of neighborhood type and self-selection on driving behavior: an application of sample selection model. Transportation 36 (2), 207-222.

Cao, X., Mokhtarian, P. L., and Handy, S. L. (2007). Cross-sectional and quasi-panel explorations of the connection between the built environment and auto ownership. Environment and Planning A 39 (4), 830-847.

Cao, X. J., and Ermagun (forthcoming). The Influences of the Hiawatha LRT on Changes in Travel Behavior: A Retrospective Study on Movers. Urban Studies.

Cao, X. J., and Schoner, J. (2014). The influence of light rail transit on transit use: An exploration of station area residents along the Hiawatha line in Minneapolis. Transportation Research Part A: Policy and Practice 59, 134-143.

Cervero, R., and Kockelman, K. (1997). Travel Demand and the 3Ds: Density, Diversity, and Design Transportation Research Part D 2 (3), 199-219.

Chatman, D. G. (2005). How the built environment influences non-work travel: Theoretical and empirical essays, University of California, Los Angeles.

Chatman, D. G. (2013). Does TOD need the T? On the importance of factors other than rail access. Journal of the American Planning Association 79 (1), 17-31.

Cherry, C. R., Weinert, J. X., and Xinmiao, Y. (2009). Comparative environmental impacts of electric bikes in China. Transportation Research Part D: Transport and Environment 14 (5), 281-290.

Crano, W. D., Brewer, M. B., and Lac, A. (2015). Principles and methods of social research, 3rd edn. Routledge, New York.

DeMaio, P. (2009). Bike-sharing: History, impacts, models of provision, and future. Journal of Public Transportation 14 (4), 41-56.

Eash, R. (1997). Incorporating urban design variables in metropolitan planning organizations' travel demand models. In "Williamsburg, VA: Conference on Urban Design, Telecommuting, and Travel Behavior", pp. 167-186. Texas Transportation Institute, Arlington.

Ewing, R., and Cervero, R. (2010). Travel and the built environment. Journal of the American Planning Association 76 (3), 265-294.

Ewing, R., Greenwald, M., Zhang, M., Walters, J., Feldman, M., Cervero, R., and Thomas, J. (2009). Measuring the impact of urban form and transit access on mixed use site trip generation ratesPortland pilot study. US Environmental Protection Agency, Washington, DC.

Gao, S., Mokhtarian, P. L., and Johnston, R. A. (2008). Exploring the connections among job accessibility, employment, income, and auto ownership using structural equation modeling. The Annals of Regional Science 42 (2), 341-356. 
Garrett, T. A., and Castelazo, M. D. (2004). Light rail transit in America: Policy issues and prospects for economic development. Working Paper, Federal Reserve Bank of St. Louis, MO.

Giuliano, G., and Dargay, J. (2006). Car ownership, travel and land use: a comparison of the US and Great Britain. Transportation Research Part A: Policy and Practice 40 (2), 106-124.

Goetzke, F., and Weinberger, R. (2012). Separating contextual from endogenous effects in automobile ownership models. Environment and Planning-Part A 44 (5), 1032.

Gossen, R. (2005). Travel Characteristics of TOD and Non-TOD Residents in the San Francisco Bay Area: Evidence from the 2000 Bay Area Travel Survey. Report for the Metropolitan Transpiration Commission, Oakland California.

Gu, Y., and Zheng, S. (2010). The Impacts of Rail Transit on Property Values and Land Development Intensity: The Case of No. 13 Line in Beijing [J]. Acta Geographica Sinica 65 (2), 213-223.

Guiliano, G. (2004). Land Use Impacts of Transportation Investments-Highway and Transit. In "The Geography of Urban Transportation" (S. Hanson and G. Giuliano, eds.), pp. 237-273. The Guilford Press, New York.

Guo, Z. (2013). Does residential parking supply affect household car ownership? The case of New York City. Journal of Transport Geography 26, 18-28.

Hess, D., and Ong, P. (2002). Traditional neighborhoods and automobile ownership. Transportation Research Record: Journal of the Transportation Research Board 1805, 35-44.

Holtzclaw, J., Clear, R., Dittmar, H., Goldstein, D., and Haas, P. (2002). Location efficiency: Neighborhood and socio-economic characteristics determine auto ownership and use-studies in Chicago, Los Angeles and San Francisco. Transportation Planning and Technology 25 (1), 1-27.

Huang, X., Cao, J., Cao, X., and Yin, J. (2016). How does the propensity of living near rail transit moderate the influence of rail transit on transit trip frequency in Xi'an? Journal of Transport Geography 54, 194-204.

Kim, H. S., and Kim, E. (2004). Effects of public transit on automobile ownership and use in households of the USA. Review of Urban \& Regional Development Studies 16 (3), 245-262.

Knowles, R. D. (1996). Transport impacts of Greater Manchester's Metrolink light rail system. Journal of Transport Geography 4 (1), 1-14.

Kockelman, K. (1997). Travel behavior as function of accessibility, land use mixing, and land use balance: evidence from San Francisco Bay Area. Transportation Research Record: Journal of the Transportation Research Board 1607, 116-125.

Li, J., Walker, J., Srinivasan, S., and Anderson, W. (2010). Modeling private car ownership in China: investigation of urban form impact across megacities. Transportation Research Record: Journal of the Transportation Research Board 2193, 76-84.

Macfarlane, G. S., Garrow, L. A., and Mokhtarian, P. L. (2015). The influences of past and present residential locations on vehicle ownership decisions. Transportation Research Part A 74, 186200.

National Bureau of Statistics of China, N. (2014). China Statistical Yearbooks 2014. China Statistics, Beijing.

Pan, H., Shen, Q., and Zhao, T. (2013). Travel and Car Ownership of Residents near New Suburban Metro Stations in Shanghai, China. Transportation Research Record: Journal of the Transportation Research Board 2394 (1), 63-69. 
Pan, H., and Zhang, M. (2008). Rail transit impacts on land use: Evidence from Shanghai, China. Transportation Research Record: Journal of the Transportation Research Board 2048 (1), 16-25.

Pinjari, A. R., Pendyala, R. M., Bhat, C. R., and Waddell, P. A. (2011). Modeling the choice continuum: an integrated model of residential location, auto ownership, bicycle ownership, and commute tour mode choice decisions. Transportation 38 (6), 933-958.

Potoglou, D., and Kanaroglou, P. S. (2008). Modelling car ownership in urban areas: a case study of Hamilton, Canada. Journal of Transport Geography 16 (1), $42-54$.

Pucher, J., Korattyswaropam, N., Mittal, N., and Ittyerah, N. (2005). Urban transport crisis in India. Transport Policy 12 (3), 185-198.

Renne, J. L. (2005). Transit-oriented development: measuring benefits, analyzing trends, and evaluating policy.Ph.D. ,Urban Planning and Policy Development Program in the Bloustein School of Planning and Public Policy, Rutgers University.

Soltani, A. (2005). Exploring the impacts of built environments on vehicle ownership. Proceedings of the Eastern Asia Society for Transportation Studies 5, 2151-2163.

Switzer, C. (2002). The Center Commons Transit Oriented Development: A Case Study. Master of Urban and Regional Planning Thesis, Portland State University, Oregan.

Van Acker, V., and Witlox, F. (2010). Car ownership as a mediating variable in car travel behaviour research using a structural equation modelling approach to identify its dual relationship. Journal of Transport Geography 18 (1), 65-74.

Weinberger, R., and Goetzke, F. (2010). Unpacking preference: How previous experience affects auto ownership in the United States. Urban studies 47 (10), 2111-2128.

Weinberger, R., Seaman, M., and Johnson, C. (2009). Residential off-street parking impacts on car ownership, vehicle miles traveled, and related carbon emissions: New York City case study. In "Transportation Research Record: Journal of the Transportation Research Board, No.2118", Vol. 2118, pp. 24-30. Transportation Research Board of the National Academies, Washington, D.C.

Xi'an Bureau of Statistics (2015). Xi'an statistical yearbook 2015. China Statistics press, Beijing.

Xing, Y., Handy, S. L., and Buehler, T. J. (2008). Factors associated with bicycle ownership and use: A study of 6 small US cities. In "Annual Meeting of the Transportation Research Board, Washington, DC".

Yamamoto, T. (2009). Comparative analysis of household car, motorcycle and bicycle ownership between Osaka metropolitan area, Japan and Kuala Lumpur, Malaysia. Transportation 36 (3), 351-366.

Zegras, C. (2010). The built environment and motor vehicle ownership and use: Evidence from Santiago de Chile. Urban Studies 47 (8), 1793-1817.

Zhang, Y., Li, Y., Yang, X., Liu, Q., and Li, C. (2013). Built Environment and Household Electric Bike Ownership: Insights from Zhongshan Metropolitan Area, China. Transportation Research Record: Journal of the Transportation Research Board 2387 (1), 102-111. 


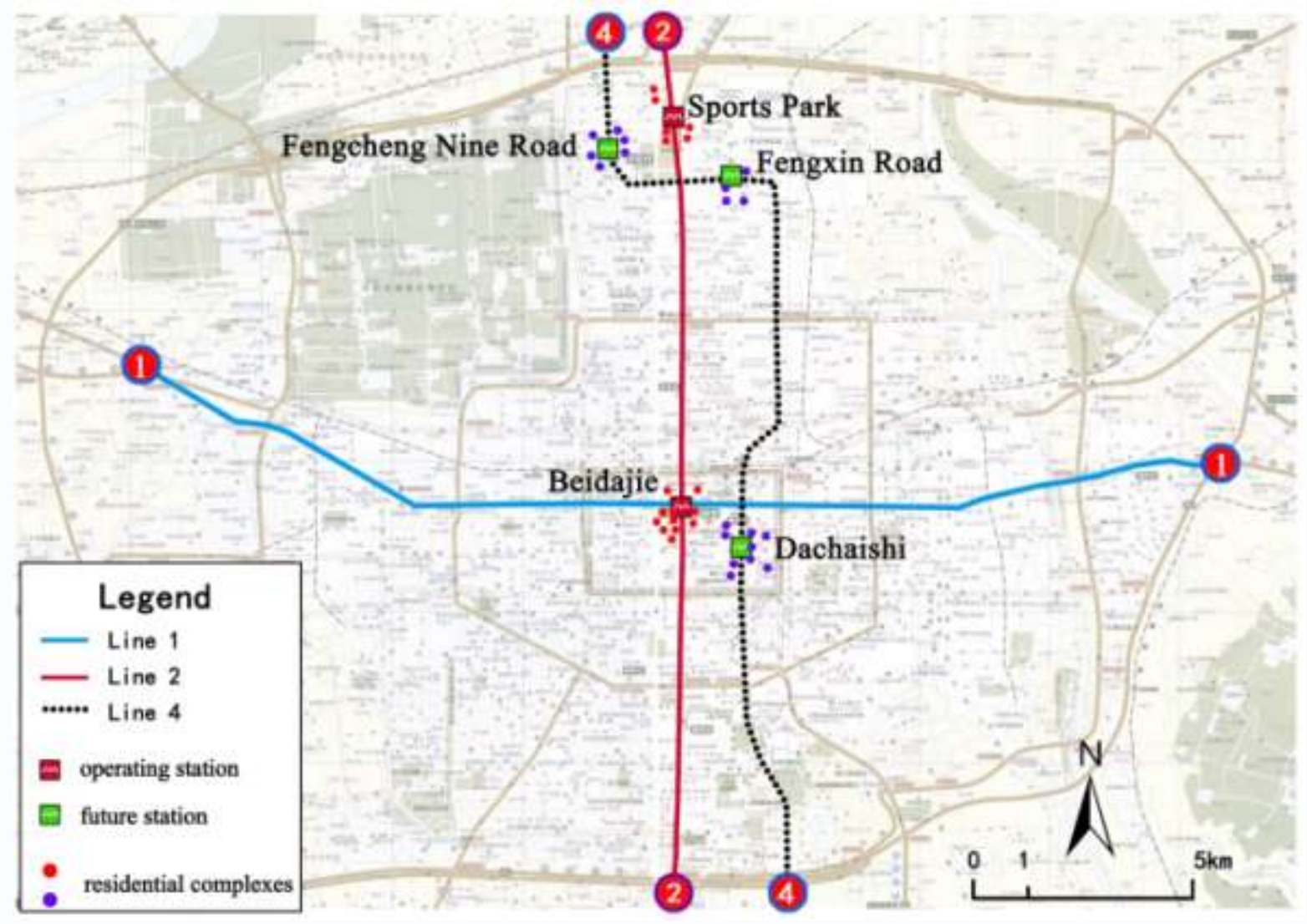

Figure 1. Location of sample residential complexes

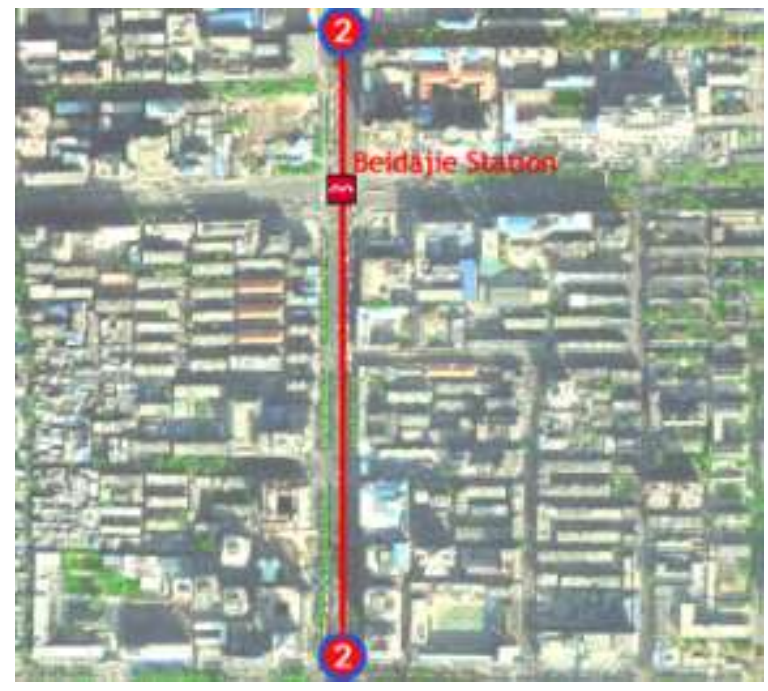

(a ) Urban residential complexes along Line 2

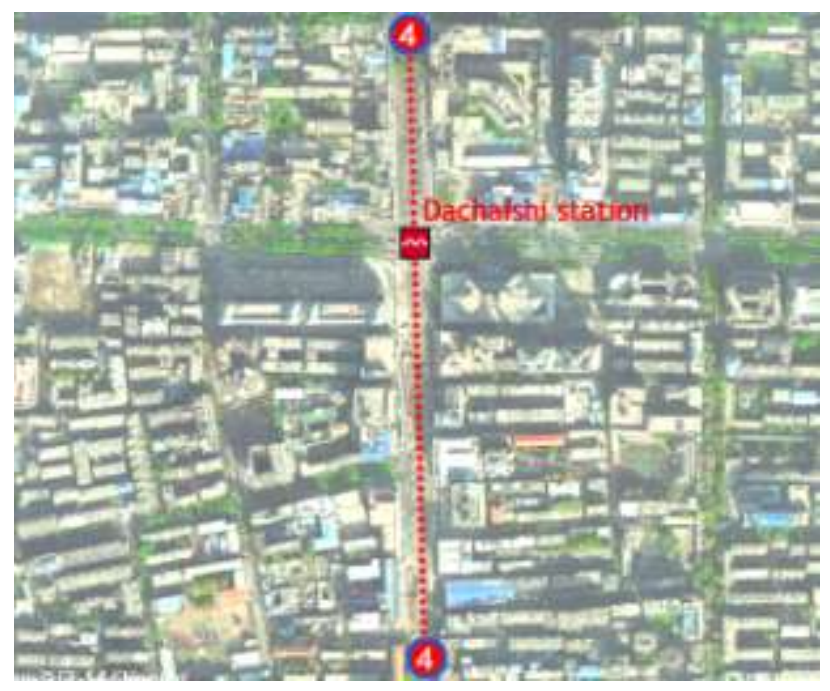

(b ) Urban residential complexes along Line 4 


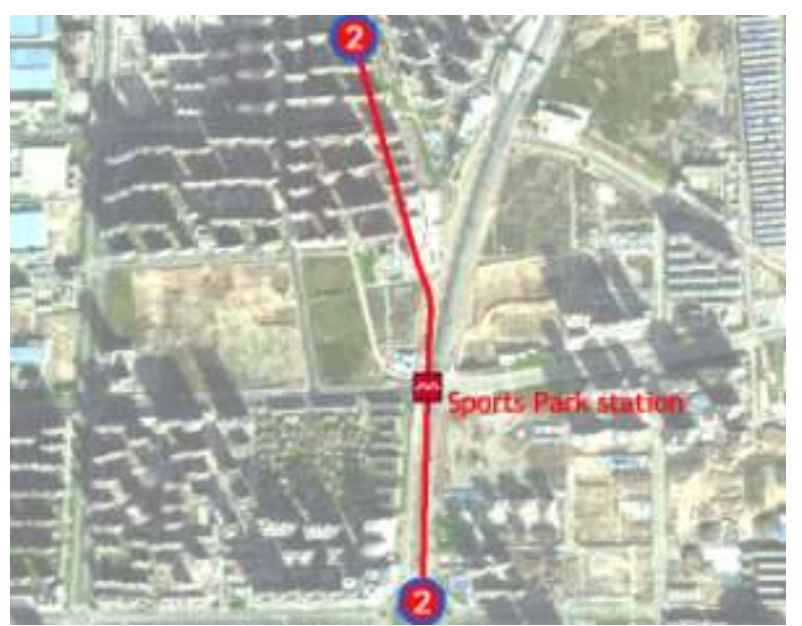

(c ) Exurban residential complexes along Line 2

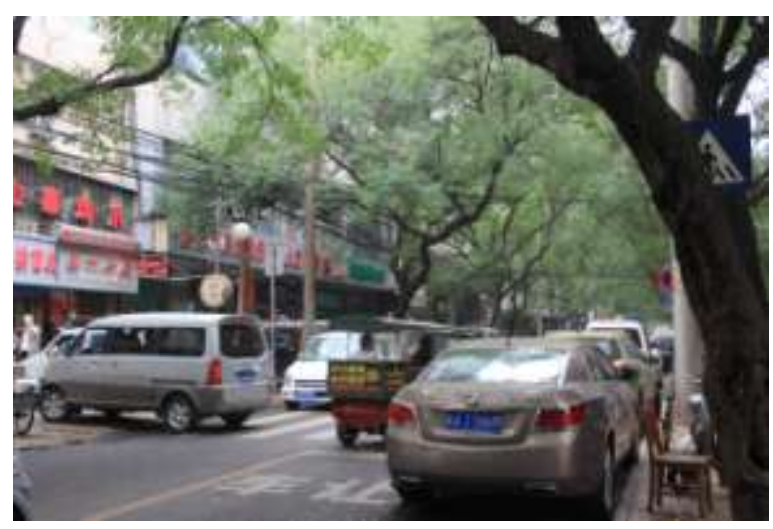

(e ) Urban streets near Line 2

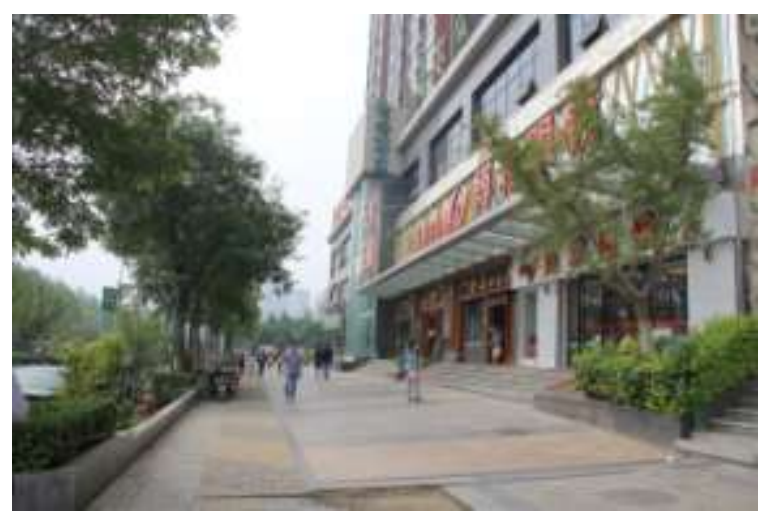

( g ) Exurban streets near Line 2

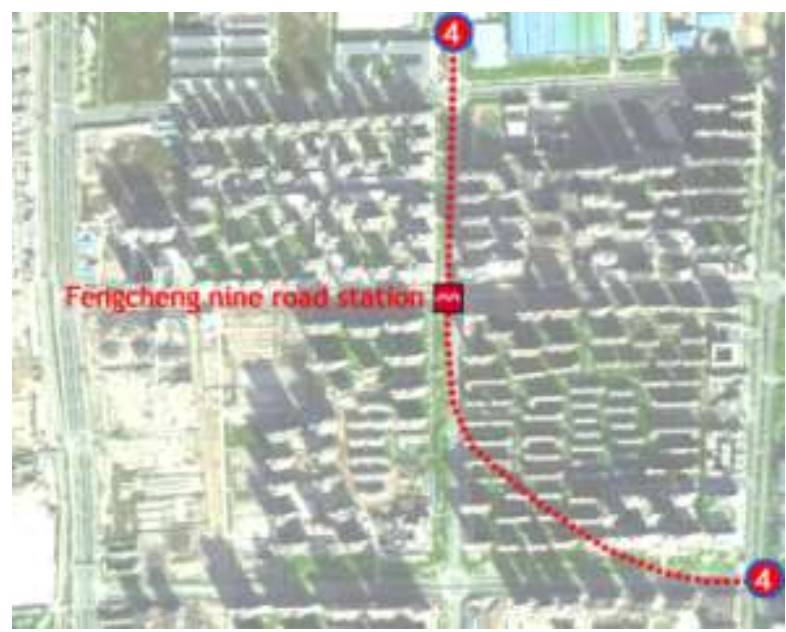

(d) Exurban residential complexes along Line 4

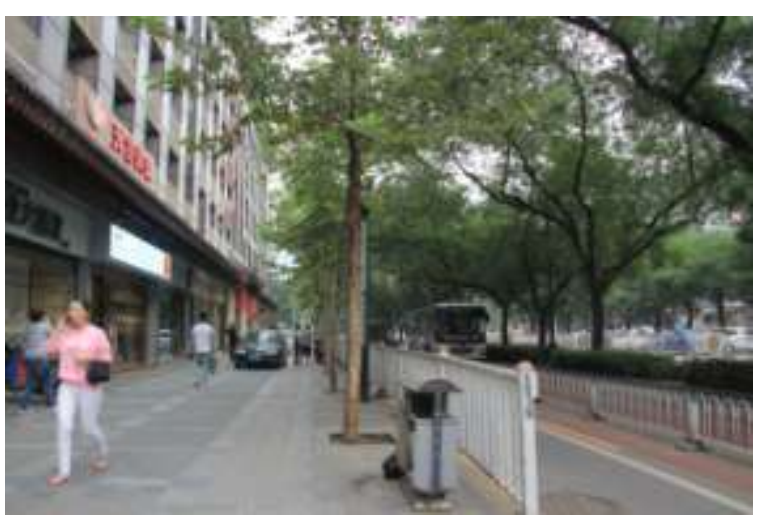

(f) Urban streets near Line 4

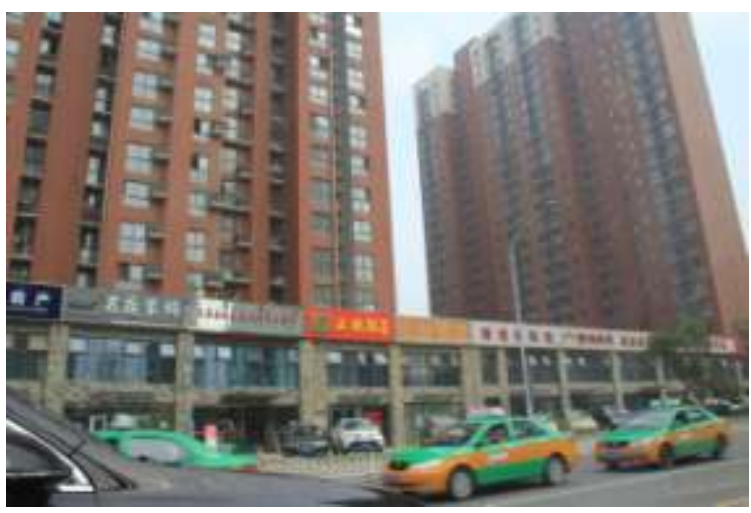

(h) Exurban streets near Line 4

Figure 2. Comparison of urban and exurban neighborhoods along Line 2 and Line 4 
Table 1. Neighborhood Attributes of Urban and Exurban Residential Complexes along Line 2 and Line 4

\begin{tabular}{|c|c|c|c|c|c|}
\hline & $\begin{array}{c}\text { Mean } \\
\text { population } \\
\text { density of } \\
\text { neighborhoods } \\
\left(\text { person per } \mathrm{km}^{2} \text { ) }\right.\end{array}$ & $\begin{array}{c}\text { Mean } \\
\text { number of } \\
\text { bus lines }\end{array}$ & $\begin{array}{c}\text { Mean } \\
\text { number of } \\
\text { bus stops }\end{array}$ & $\begin{array}{c}\text { Mean road } \\
\text { density } \\
\left(\mathrm{km} / \mathrm{km}^{2}\right)\end{array}$ & $\begin{array}{l}\text { Number of } \\
\text { residential } \\
\text { complexes }\end{array}$ \\
\hline Exurban & 6778.00 & 15.40 & 6.66 & 4.75 & 29 \\
\hline Line4 (Control) & 5259.25 & 15.60 & 8.23 & 4.78 & 12 \\
\hline Line2 (Metro) & 8193.04 & 15.21 & 5.21 & 4.73 & 17 \\
\hline P-value (Line4 and Line2) & 0.00 & 0.53 & 0.00 & 0.73 & - \\
\hline Urban & 24816.65 & 47.67 & 12.64 & 8.97 & 30 \\
\hline Line4 (Control) & 21681.84 & 54.81 & 13.12 & 9.89 & 21 \\
\hline Line2 (Metro) & 27951.47 & 40.53 & 12.17 & 8.05 & 9 \\
\hline P-value (Line4 and Line2) & 0.00 & 0.55 & 0.00 & 0.95 & - \\
\hline P-value (urban and exurban) & 0.00 & 0.00 & 0.00 & 0.26 & - \\
\hline
\end{tabular}


Table 2. Sample Demographic Characteristics for Different Corridors

\begin{tabular}{|c|c|c|c|c|c|c|c|c|c|}
\hline \multirow[b]{2}{*}{ variables } & \multicolumn{4}{|c|}{ Exurban } & \multicolumn{4}{|c|}{ Urban } & \multirow[b]{2}{*}{$\begin{array}{c}\mathrm{P}- \\
\text { value }\end{array}$} \\
\hline & $\begin{array}{c}\text { All } \\
\text { exurban } \\
\text { sample }\end{array}$ & $\begin{array}{c}\text { Line4 } \\
\text { (Control) }\end{array}$ & $\begin{array}{l}\text { Line2 } \\
\text { (Metro) }\end{array}$ & $\begin{array}{c}\mathrm{P}- \\
\text { value }\end{array}$ & $\begin{array}{c}\text { All } \\
\text { urban } \\
\text { sample } \\
\end{array}$ & $\begin{array}{c}\text { Line4 } \\
\text { (Control) }\end{array}$ & $\begin{array}{c}\text { Line2 } \\
\text { (Metro) }\end{array}$ & P-value & \\
\hline$\%$ female & 0.49 & 0.56 & 0.43 & 0.01 & 0.51 & 0.52 & 0.53 & 0.84 & 0.01 \\
\hline Mean age & 38.7 & 42.4 & 35.3 & 0.00 & 41.7 & 44.8 & 38.5 & 0.00 & 0.00 \\
\hline Mean education & 4 & 3.71 & 4.27 & 0.00 & 3.98 & 3.79 & 4.16 & 0.00 & 0.00 \\
\hline $\begin{array}{l}\text { Mean household } \\
\text { size }\end{array}$ & 3.87 & 3.9 & 3.84 & 0.72 & 3.7 & 3.39 & 4.01 & 0.00 & 0.01 \\
\hline Mean income & 3.23 & 2.96 & 3.49 & 0.00 & 2.58 & 2.27 & 2.88 & 0.00 & 0.00 \\
\hline $\begin{array}{l}\text { Mean auto } \\
\text { ownership }\end{array}$ & 0.59 & 0.62 & 0.55 & 0.75 & 0.63 & 0.64 & 0.62 & 0.30 & 0.35 \\
\hline $\begin{array}{l}\text { Mean motor } \\
\text { ownership }\end{array}$ & 0.13 & 0.09 & 0.16 & 0.49 & 0.12 & 0.1 & 0.13 & 0.05 & 0.06 \\
\hline $\begin{array}{l}\text { Mean bike } \\
\text { ownership }\end{array}$ & 0.48 & 0.37 & 0.59 & 0.12 & 0.47 & 0.42 & 0.51 & 0.00 & 0.00 \\
\hline $\begin{array}{l}\text { Mean ebike } \\
\text { ownership }\end{array}$ & 0.47 & 0.49 & 0.45 & 0.07 & 0.41 & 0.47 & 0.37 & 0.56 & 0.11 \\
\hline $\begin{array}{l}\text { Number of } \\
\text { respondents }\end{array}$ & 396 & 191 & 205 & 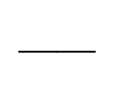 & 386 & 193 & 193 & - & 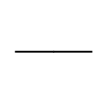 \\
\hline
\end{tabular}

Notes: the p-values in the column block for urban indicate the significant level of the differences between Line 4 and Line 2 in urban areas; the p-values in the column block for exurban indicate the significant level of the differences between Line 4 and Line 2 in exurban areas; and the last p-values indicate the significant level of the differences between Line 4 and Line 2 for the entire sample in urban and exurban areas. 
Table 3. Sample Demographic Characteristics of Movers and Non-movers

\begin{tabular}{|c|c|c|c|c|c|c|c|c|c|}
\hline & \multicolumn{3}{|c|}{ All } & \multicolumn{3}{|c|}{ Line2 (Metro) } & \multicolumn{3}{|c|}{ Line4 (Control) } \\
\hline & Mover & $\begin{array}{l}\text { Non- } \\
\text { mover }\end{array}$ & $\begin{array}{l}\mathrm{P} \text { - } \\
\text { value }\end{array}$ & Mover & $\begin{array}{l}\text { Non- } \\
\text { mover }\end{array}$ & P-value & Mover & $\begin{array}{l}\text { Non- } \\
\text { mover }\end{array}$ & $\begin{array}{l}\mathrm{P} \text { - } \\
\text { value }\end{array}$ \\
\hline$\%$ female & 0.51 & 0.5 & 0.71 & 0.47 & 0.51 & 0.59 & 0.56 & 0.49 & 0.19 \\
\hline Mean age & 36.35 & 52.25 & 0 & 34.47 & 48.51 & 0 & 38.7 & 54.33 & 0 \\
\hline Mean education & 4.15 & 3.4 & 0 & 4.29 & 3.69 & 0 & 3.98 & 3.24 & 0 \\
\hline $\begin{array}{l}\text { Mean household } \\
\text { size }\end{array}$ & 3.84 & 3.61 & 0.6 & 3.9 & 4.03 & 0.5 & 3.76 & 3.38 & 0.22 \\
\hline Mean income & 3.11 & 2.26 & 0 & 3.3 & 2.67 & 0 & 2.88 & 2.03 & 0 \\
\hline $\begin{array}{l}\text { Number of } \\
\text { respondents }\end{array}$ & 595 & 187 & - & 331 & 67 & - & 264 & 120 & \\
\hline
\end{tabular}


Table 4. Measurement Models of Residential Preferences and Perception

\begin{tabular}{|c|c|c|c|}
\hline Statements & Safety & Transit & Accessibility \\
\hline Low crime rate within neighborhood & 0.69 & & \\
\hline Low level of auto traffic on neighborhood streets & 0.58 & & \\
\hline Quiet neighborhood & 0.62 & & \\
\hline Good street lighting & 0.60 & & \\
\hline Safe neighborhood for walking & 0.51 & & \\
\hline Safe neighborhood for kids to play outdoors & 0.64 & & \\
\hline Good public transit service (bus or rail) & & 0.54 & \\
\hline Easy access to transit stop/station & & 0.53 & \\
\hline $\begin{array}{l}\text { Living unit is convenient and near main street and } \\
\text { convenient street }\end{array}$ & & & 0.89 \\
\hline Parks and open spaces nearby & & & 0.61 \\
\hline Shopping areas within walking distance & & & 0.63 \\
\hline Easy access to a regional shopping mall & & & 0.53 \\
\hline Easy access to downtown & & & 0.60 \\
\hline Religious or civic buildings (ex., library) nearby & & & 0.72 \\
\hline Close to where I work & & & 0.82 \\
\hline
\end{tabular}

$\begin{array}{ll}\text { Attractive appearance of neighborhood } & 0.41\end{array}$

$\begin{array}{ll}\text { Variety in housing styles } & 0.34\end{array}$

High level of upkeep in neighborhood $\quad 0.78$

$\begin{array}{ll}\text { Sidewalks throughout the neighborhood } & 0.47\end{array}$

$\begin{array}{ll}\text { Good bike routes beyond the neighborhood } & 0.55\end{array}$

More contacts between neighborhood people 0.42

Economic level of neighbors similar to my level 0.49

Notes: All coefficients are standardized and significant at the 0.01 level.

Goodness-of-fit measures: Root mean squared error of approximation (RMSEA) $=0.066<0.08$; Standardized root mean squared residual

$(\mathrm{SRMR})=0.049<0.08 ;$ Comparative fit index $(\mathrm{CFI})=0.913$. 
Table 5. Measurement Models of Travel Attitudes

\begin{tabular}{|c|c|c|c|c|c|}
\hline Statements & $\begin{array}{l}\text { Safety of } \\
\text { auto }\end{array}$ & $\begin{array}{l}\text { Pro- } \\
\text { transit }\end{array}$ & $\begin{array}{l}\text { Pro- } \\
\text { drive }\end{array}$ & Pro-bike & $\begin{array}{l}\text { Pro- } \\
\text { walk }\end{array}$ \\
\hline $\begin{array}{l}\text { Traveling by auto is safer overall than taking } \\
\text { transit }\end{array}$ & 0.73 & & & & \\
\hline $\begin{array}{l}\text { Traveling by auto is safer overall than riding } \\
\text { a bike }\end{array}$ & 0.66 & & & & \\
\hline $\begin{array}{l}\text { Traveling by auto is safer overall than } \\
\text { walking }\end{array}$ & 0.59 & & & & \\
\hline $\begin{array}{l}\text { I prefer to take transit rather than drive } \\
\text { whenever possible }\end{array}$ & & 0.54 & & & \\
\hline $\begin{array}{l}\text { Public transit can sometimes be easier for } \\
\text { me than driving }\end{array}$ & & 0.53 & & & \\
\hline I like taking transit & & 0.89 & & & \\
\hline I like driving & & & 0.63 & & \\
\hline I like to drive just for fun & & & 0.60 & & \\
\hline I feel free and independent if I drive & & & 0.60 & & \\
\hline I like riding a bike & & & & 0.80 & \\
\hline $\begin{array}{l}\text { I prefer to bike rather than drive whenever } \\
\text { possible }\end{array}$ & & & & 0.42 & \\
\hline $\begin{array}{l}\text { Biking can sometimes be easier for me than } \\
\text { driving }\end{array}$ & & & & 0.76 & \\
\hline $\begin{array}{l}\text { I prefer to walk rather than drive whenever } \\
\text { possible }\end{array}$ & & & & & 0.51 \\
\hline $\begin{array}{l}\text { Walking can sometimes be easier for me } \\
\text { than driving }\end{array}$ & & & & & 0.79 \\
\hline I like walking & & & & & 0.60 \\
\hline
\end{tabular}

Notes: All coefficients are standardized and significant at the 0.01 level.

Goodness-of-fit measures: Root mean squared error of approximation $($ RMSEA $)=0.054<0.08$;

Standardized root mean squared residual $(\mathrm{SRMR})=0.046<0.08$; Comparative fit index $(\mathrm{CFI})=0.905$. 
Table 6. Mixed-process models for auto, motor, bike and ebike ownership

\begin{tabular}{|c|c|c|c|c|c|c|c|c|}
\hline \multirow{2}{*}{ Variables } & \multicolumn{2}{|c|}{ Auto } & \multicolumn{2}{|c|}{ Motorcycle } & \multicolumn{2}{|c|}{ Bike } & \multicolumn{2}{|c|}{ Ebike } \\
\hline & Coeff. & $\mathbf{P}$ & Coeff. & $\mathbf{P}$ & Coeff. & $\mathbf{P}$ & Coeff. & $\mathbf{P}$ \\
\hline Metro & -0.339 & 0.000 & 0.164 & 0.184 & 0.233 & 0.011 & -0.181 & 0.048 \\
\hline Age & 0.009 & 0.004 & -0.012 & 0.003 & -0.007 & 0.027 & -0.009 & 0.006 \\
\hline Household income & 0.269 & 0.000 & -0.107 & 0.027 & -0.074 & 0.049 & -0.066 & 0.078 \\
\hline Household size & & & 0.094 & 0.014 & 0.162 & 0.000 & 0.119 & 0.000 \\
\hline Number of drivers & 0.649 & 0.000 & & & 0.120 & 0.009 & & \\
\hline Education & & & & & & & -0.081 & 0.084 \\
\hline License & 0.273 & 0.008 & & & & & & \\
\hline Pro-drive attitude & 0.287 & 0.000 & & & & & & \\
\hline Pro-bike attitude & & & & & 0.166 & 0.006 & 0.124 & 0.037 \\
\hline Safety of auto & & & & & -0.185 & 0.039 & & \\
\hline Number of observations & 782 & & & & & & & \\
\hline Rho_auto_motorcycle & -0.157 & 0.078 & & & & & & \\
\hline Rho_auto_bike & -0.060 & 0.055 & & & & & & \\
\hline Rho_auto_ebike & -0.201 & 0.055 & & & & & & \\
\hline Rho_motorcycle_bike & 0.103 & 0.071 & & & & & & \\
\hline Rho_motorcycle_ebike & 0.112 & 0.071 & & & & & & \\
\hline Rho_bike_ebike & 0.056 & 0.053 & & & & & & \\
\hline
\end{tabular}


Table 7. Mixed-process models for change vehicles

\begin{tabular}{lccccccccc}
\hline \multirow{2}{*}{ Variables } & \multicolumn{2}{c}{$\begin{array}{c}\text { Change_ } \\
\text { auto }\end{array}$} & \multicolumn{3}{c}{$\begin{array}{c}\text { Change_ } \\
\text { Motorcycle }\end{array}$} & \multicolumn{2}{c}{ Change_bike } & \multicolumn{2}{c}{ Change_ebike } \\
\cline { 2 - 10 } & Coeff. & P & Coeff. & P & Coeff. & P & Coeff. & P \\
\hline Metro & -0.481 & 0.000 & -0.140 & 0.262 & -0.148 & 0.151 & -0.215 & 0.042 \\
Change of Household size & 0.143 & 0.001 & 0.152 & 0.002 & 0.085 & 0.036 & 0.114 & 0.009 \\
Change of income & 0.119 & 0.011 & & & -0.147 & 0.001 & & \\
\hline Number of observations & 595 & & & & & & & \\
Rho_auto_motorcycle & 0.047 & 0.547 & & & & & & \\
Rho_auto_bike & -0.393 & 0.530 & & & & & & \\
Rho_auto_ebike & -0.168 & 0.011 & & & & & & & \\
Rho_motor_bike & 0.138 & 0.054 & & & & & & & \\
Rho_motor_ebike & 0.002 & 0.982 & & & & & & & \\
Rho_bike_ebike & 0.001 & 0.986 & & & & & & & \\
\hline
\end{tabular}

